\title{
A complexity related to mapping and classification of urban soils (a case study of Bratislava city, Slovakia)
}

\author{
Jaroslava Sobocká1, Martin Saksa ${ }^{1 *}$, Daniel Szatmári², Ján Feranec ${ }^{2}$, Monika Kopecká2 \\ ${ }^{1}$ National Agriculture and Food Centre, Soil Science and Conservation Research Institute, Department of General Pedology and Pedogeography, \\ Trenčianska 55, 821 09, Bratislava, Slovakia \\ ${ }^{2}$ Slovak Academy of Sciences, Institute of Geography, Štefánikova 49, 814 73, Bratislava, Slovakia \\ * PhD. M. Saksa, martin.saksa@nppc.sk, ORCID iD: https://orcid.org/0000-0001-8902-1905
}

Received: 15.06 .2020

Accepted: 15.09.2020

Associated editor: C. Kabała

\section{Keywords}

Anthropogenic soils

Soil mapping

Soil classification

Pedo-urban complex

Soil sealing

Bratislava

\begin{abstract}
The issue of the urban soil survey, mapping and classifications (including urban soil diagnostics) seems to be not unified and standardized in the last time research. To contribute to the knowledge profound, we present procedure of the urban soil mapping which was based on the concept of pedo-urban complexes enabling to map urban soils in large or middle-sized scale. The mapping process includes the use of multiple background materials such as land cover/land use map, digital terrain model, satellite images, and soil survey results in the field. The example of this mapping method was demonstrated on Bratislava City in Slovak republic. The Slovak Morphogenetic Soil Classification system (MKSP 2014) and World Reference Base for Soil Resources (WRB 2015) was used for soil map unit's classification. Concept of the pedo-urban complex (PUC) includes several mapping attributes: urban land use, mapping of soil sealing, mapping of soil units (prevailingly soil association) as well as technogenic substrates. This basis was completed by soil texture, and level of environmental risk. PUC can create some spatial pattern depending on urban land use. Other soil areas are delineated as natural soil types variously influenced by geomorphology or pedology setting. The result of this process is creation of the soil map of Bratislava City which consists of 1,478 areas with soil units. Soil map could be applied in urban planning processes, as very detailed information provided within the map. Also it can be showed some gaps in mapping which should be the topic of further discussions and studies.
\end{abstract}

\section{Introduction}

Urban soil research has been developed very rapidly in recent decades (De Kimpe and Morel, 2000). Certini and Scalenghe (2011) talk about a new era - Anthropocene, where anthropogenic soils and their research plays an important role in this challenge. There is also a need to mention that soil sealing was identified as the greatest threat, leading to the deteriorating of land in many European countries (Montanarella et al., 2016).

However, despite several decades of urban land research and development over the world, mapping and classification of urban soils is not sufficiently resolved and standardized. This status can be attributed to the quick and non-coordinated urban soil research rather scattered in countries and locally in cities, as well as to different concepts or systems of cartographic processing to compare at various level of investigation (Levin et al., 2017).

Many countries have begun to develop anthropogenic soil classification systems, most of which are very diverse with setting different classification concept. In addition, there is termi- nological and nomenclatural inconsistency as well as urban soil definition, which makes it difficult to study these soils. Various terminological terms have emerged resulting in not unified terminology and still a weak consensus in the uniform understanding of concepts. Similarly, taxonomic systems to address identification, inventory, and interpretation these soils have been presented in several works, and their naming has been and still is born. Some examples can be mentioned. The term "urban soil" was introduced by Bockheim (1974) as material that has been manipulated, disturbed or transported by man `s activities in the urban environment and is used as a medium for plant growth. Burghardt (1994) understands these soils as a general terminological concept for soils occurring in urban, industrial, traffic, mining and military areas. Lehmann and Stahr (2007) present anthropogenic urban soils, Stroganova et al. (1997) works with the concept of Urbanozems as urban soil type. An example of a Russian school is ordering these soils from the classification of natural soils and their naming as "surface to soil similar formations" and later their incorporation into the Russian classification system (Prokofyeva et al., 2014). Rossiter (2007) presented 
urban and industrial conditions and discussed the term "urban soil”. He had a very progressive role in creating a new soil group Technosols Group in WRB 2006 (IUSS Working Group WRB, 2006). The latest World Reference Base for soils sources (IUSS Working Group WRB, 2015) defines anthropogenic as a classification system such as those with anthropogenic diagnostic features that are partially identified. Sobocká (2003) distinguishes the term "urban soils" as general terminology for soils occurring in urban, industrial, transport, mining and military areas; and the term "anthropogenic soils" as term for soils classified according to anthropogenic diagnostic features and materials, i.e. classification concept. Recently, the term SUITMA soils (Charzyński et al., 2013), which mean soils occurring in urbanized, industrial, transport, mining and military areas, was establish. This term is used as an abbreviation for the SUITMA working group in IUSS (Morel and Heinrich, 2008) and introduced this abbreviation for the general naming of these soils.

In many cases, these soils are classified according to the classification of natural soils, if they are in the initial stage of development (for example Regosols, Rendzinas, etc. in the German classification - Deutschen Bodekundlichen Geselschaft, 1998) or Entisols, or Inceptisols in Soil Taxonomy USDA (Soil Survey Staff, 2014). Technogenic surface formations are solved in another way (Tonkonogov and Lebedeva, 1999) or anthropogenic artificial or reconstructed soils in French classification system (Blaize, 1998). Charzyński et al. (2013) focused on classification technogenic under the WRB system and their incorporation into the Polish classification system, similar to Puskás and Farsang (2009) evaluated the properties of technogenic soils according to WRB 2006. In addition, in urbanized areas we can found:

i) natural soils and semi-natural soils (non-disturbed or slightly disturbed soils) - e.g. urban forest parks, natural reservations, protected areas

ii) partially changed soils - physically or chemically disturbed (e.g. soils with original morphology, but having altered soil chemistry due to emission spillage

iii) human-changed soils (changed by deep cultivation, soils developed in-situ) - anthropogenic soils (Kultizems)

iv) human-made soils (artificial) soils (human-transported and transformed soils) - anthropogenic soils (Technozems)

Two new groups of anthropogenic soils are in the Morphogenetic Soil Classification system of Slovakia - MKSP 2014 (Societas pedologica slovaca, 2014): 1) group under cultivation having two types: Cultizem and Hortizem (soil "in situ” deeply transformed and 2) a group of technogenic soils having: Anthrozem and Technozem (soils developed from transported and altered substrates ex-situ soils. This concept is also followed by the latest classification system under the World Reference Base of Soil Resources (IUSS Working Group IUSS, 2006; IUSS Working Group WRB, 2015).

Soil mapping in urban areas is even a bigger issue due to the variable and complicated urban land surface. In cities areas many land use forms are recognized like historical centers, industrial plants, urban green and parks, playgrounds and schoolyards, residential areas, recreation areas, abandoned brownfields, etc. Survey and mapping of urban soils (mainly Technosols) are considered to be complicated and complex task (Greinert, 2015;
Shaw et al. 2018). Human activities have played an overwhelming role in the distribution of soils or parent materials within the city, which have strong impact on different pedogenetic and human-induced processes. Urban soil spatial variability contributes strongly to this complexity and pedodiversity (Schleuss et al., 1998; Pindral et al., 2020). Therefore, having a good understanding of pedogenesis and history is strongly recommended to the whole urban landscape study. Generally, soils in cities can be completely scalped and stockpiled or backfilled around the construction objects. These are mostly belonging to the soil group Technosols (IUSS Working Group WRB, 2015).

In most cities there are available data concerning soils and their various properties. Also methodological approaches, which include urban soil surveys; sampling and soil properties evaluation for urban planning and zoning processes have been revealed throughout the world, like TUSEC-IP (Lehmann, 2009), and other publications on urban soil assessment in landscapes (Craul, 1992; Craul 1999; Vrščaj et al., 2008). Most of these approaches attempt to assess urban soils from the viewpoint of different soil functions (Bullock and Gregory, 1991; Stroganova et al., 1997). Latest studies relating to various mapping techniques and concepts of urban soil survey revealed in several world's cities like New York (Hernandez and Galbraith, 1997; Huot et al., 2017; Shaw and Isleib, 2017), Moscow (Stroganova et al., 1997; Stroganova et al., 1998; Prokofyeva et al., 2011; Prokofyeva et al., 2014; Prokofyeva and Martynenko, 2017), several German cities (Holland et al., 1997; Schleuss et al., 1998; Fachhochschule Osnabrück, 2009; Stadt Stuttgart, 2016; Makowsky and Schneider, 2017), Toruń (Charzyński et al., 2013; Charzyński and Hulisz, 2017) and Zielona Góra (Greinert, 2015; Hulisz et al., 2018) or Inowrocław (Pindral et al., 2020).

There is a need to mention some difficulties facing urban soil survey:

- Human-transported and altered material (HTAM) - soil properties are attributable to their origin (prevailingly from technogenic or semi-technogenic substrata); and to the manner of their disturbance rather than natural pedogenetic processes (Bragina and Gerasimova, 2017; Shaw and Isleib, 2017)

- $\quad$ Soil sealing mapping (Charzyński et al., 2017)

- Young soils (i.e. initial development of soils) - the time period is too short for diagnostic horizons to form (Burghardt, 2001)

- Construction soils - civil engineering activities of man-made soils

- Mostly extreme physical (artificial compaction, artefacts stoniness, etc.) and chemical properties not obvious in natural landscapes (noxious substances)

- Mostly exceeded content of dust $\left(\mathrm{PM}_{10}\right)$, risk elements (contaminants) and pathogenic organisms (Makowsky, 2009)

- $\quad$ Presence of artifacts (IUSS Working Group WRB, 2006; IUSS Working Group WRB, 2015).

The aim of the study is to contribute to the principles and techniques of urban soil survey and mapping on the case study of Bratislava city. The methodology includes state-of-the-arts methods using for spatial distribution of soil unit's delineation (digitalized satellite images, digital terrain model). The core of 
urban soil mapping lies on the concept of pedo-urban complexes enabling to map urban soils in large or middle-sized scale. The mapping process in the field included results of the former soil survey mapping (Sobocká, 2007), and supporting by the system of soil sealing mapping, using classification diagnosed in accordance with MKSP 2014 (Societas pedologica slovaca, 2014). A correlation of soil units with those in the WRB 2015 (IUSS Working Group WRB, 2015) was made. Also some obstacles referring to urban soil survey aspects during the mapping process have been taken into consideration.

\section{Materials and methods}

\subsection{Study area}

Bratislava is middle-sized city situated in south-westernmost part of Slovakia $\left(48^{\circ} 08^{\prime} 196^{\prime \prime}\right.$ N, $17^{\circ} 06^{\prime} 178^{\prime \prime}$ E), occupying both banks of the Danube River and the left bank of Morava (March) River. Its location on the borders with Austria and Hungary makes it the only national capital that borders between two countries. The city has a total area of $367 \mathrm{~km}^{2}$ and population officially more than 430,000 citizens. Population density is about $1,190 / \mathrm{km}^{2}$.

Three dominant geomorphological units can be distinguished based on the topography (Mazúr and Lukniš, 1980), geology (Geological map of Slovakia M 1:50,000) and soil cover (Hraško et al., 1990; Sobocká, 2007) within the city borders. Two lowlands, Podunajská (Danube) lowland and Záhorská lowland, and also Malé Karpaty (Little Carpathians) Mountains. Both lowlands are part of the great Pannonian basin, differentiated by various parent material and hydrological conditions. Záhorská lowland adjacent to Morava River, is formed by Neogene sediments covered with Quaternary material forming old river terraces in several historical stages. Aeolian sands of Würm age prevails, and Arenosols (IUSS Working Group WRB, 2015) represent typical soil type. Less common are Phaeozems and Fluvisols developed from fluvial sediments of Morava River. Very fertile soils as Chernozems, Phaeozems and Fluvisols mostly calcareous (IUSS Working Group WRB, 2015) are situated in the Danubian lowland. This inland river delta is formed by Sarmat-Pannonian Neogene filling covered by Holocene fluvial sediments (gravel, sand, clay and sandstone). The Northern part of the city occupies Little Carpathians Mountains mostly forested. The Little Carpathians is part of the Western Carpathians Mountains built by crystalline rocks (shales, diorites, pegmatite and granitic rocks) and remnants of the old Mesozoic sea (marls, dolomites, limestone, sandstones). Soil cover is represented by Luvisols and Cambisols, but also Rendzic Leptosols.

The built-up area of Bratislava represents areas of land strongly disturbed by anthropogenic activity. Soil cover is recognized as open areas in the form of ornamental gardens, street alleys, recreational areas, playgrounds and schoolyards, cemeteries, city parks, etc. These are soils that we classify as Kultizems and Anthrozems in MKSP 2014 (Societas pedologica slovaca, 2014). Soils formed from human-transported and altered technogenic material are not related to ecological environment, they are significantly azonal and consists exclusively of human civil engineering activities. It should be noted that soils are significant by their diversity and dynamics showing features created by entropic way.

According to Köppen-Geigers's climate classification, Bratislava is located mainly in the Cfb climate zone, which is generally described as oceanic climate, warm temperate, fully humid with a warm summer (Kottek et al., 2006). Little Carpathians' part of the city belong to Dfb continental climate zone.

According to measurements of Slovak Hydrometeorological Institute, Bratislava has mean annual temperature (1990-2009) of around $10.5^{\circ} \mathrm{C}$ (average temperature of $21^{\circ} \mathrm{C}$ in the warmest month (July) and $-1^{\circ} \mathrm{C}$ in the coldest month (January)), four distinct seasons and mean total annual precipitation $565 \mathrm{~mm}$. It is often windy with a marked variation between hot summers and cold, humid winters. The city is one of the warmest and driest part in Slovakia.

\subsection{Soil mapping technique of the pedo-urban complex}

Pedon/polypedon and pedotope are pedological/pedo-geographic \& cartographic unit, relatively pedologically homogeneous and mapped on large scales; accounted for about $85 \%$ of the area, other pedons have a transition character. Delineation of soil units, respect natural or semi-natural cartographic lines meeting classification criteria - pedological, geomorphology, georelief. Usually there are soil type and soil associations, parent material, texture, chemical-physical properties, etc. Pedo-urban complex (PUC) is a geographical \& cartographical unit for mapping system of abiotic, biotic and socio-economic components of the urban ecosystem; assessed in relation to the SUITMA areas; in topic or choric level (large, middle or small mapping scales). Part of the pedo-urban complex can be imperviously or semi-imperviously sealed (buildings, asphalt paving, concrete, traffic networks, etc.). Urban ecosystem land use (industrial areas, housing estate, commercial areas, transport infrastructure, etc.) results in of spatial differentiation of urban soil cover. Delineation of pedo-urban complexes respects artificial cartographic lines (land cover/land use). Specific mapping criteria are involved: land cover/land use (typical pattern), soil type (soil unit's association), soil sealing percentage (variety of Technosols), parent material (technogenic substrate thickness), soil texture, chemical properties, and risk assessment (potential). This system was used in Sobocká (2007), Sobocká (2011) and showed as scheme on the Fig. 1.

In cities, there are various soil types Greinert (2015), Burghardt et al. (2015) although Prokofyeva and Martynenko (2017) claims that soil cover tends to be especially "homogenized" within the historical downtown, there are no significant differences in the soil cover composition. A great variety with strong heterogeneity in vertical direction (e.g. through soil profile) or horizontal direction (spatial differentiation) can be found within the whole city, and mainly natural soil types contribute to the higher pedodiversity as follows:

(i) natural, semi-natural soils

(ii) partially changed soils

(iii) human-changed soils

(iv) human-made soils (artificial) soils 


\section{Soils to be find within the city boundaries}

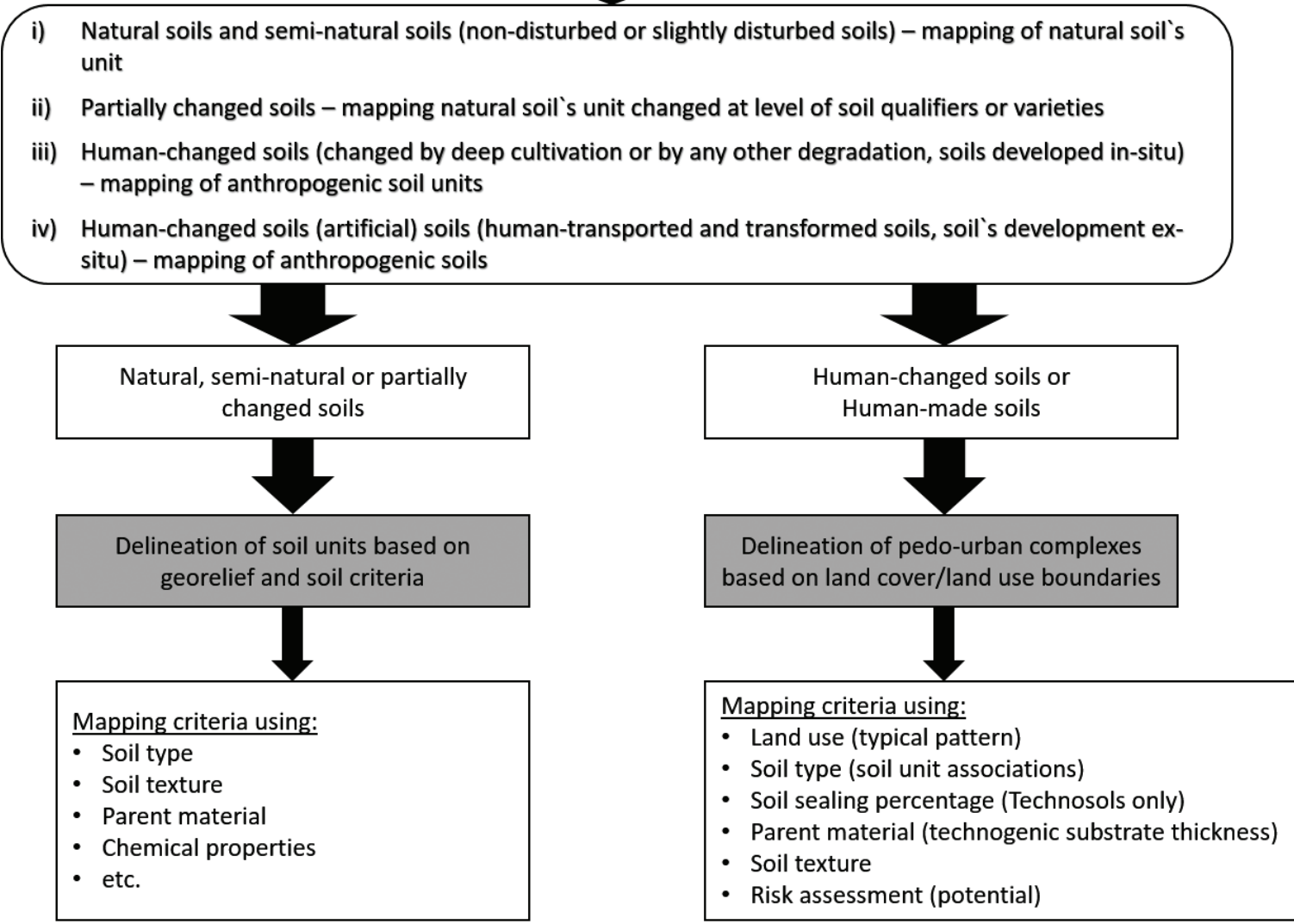

Fig. 1. Concept of Urban Soil Mapping

Data necessary for PUC mapping can involve: soil survey of urban soils and database notebook, historical documents on the sites, laboratory analyses of samples (risk assessment), digitalized satellite images, land cover/land use map, human-transported and altered technogenic substrates, and soil sealing percentage assessment.

\subsection{Soil sealing mapping and delineation of land use areas}

Mapping of impermeable soil cover was obtained from a land cover/land use map created according Extended nomenclature Urban Atlas 2012 (Szatmári et al., 2018) and Copernicus (EU) nomenclature and subsequent land cover/land use (LC/LU) classification (Feranec et al., 2019a, 2019b).

Areas of these classes are rasters with minimum area of 1 ha $(100 \times 100 \mathrm{~m})$ and a minimum width of the linear elements of $20 \mathrm{~m}$. Their identification (using satellite images) was based on the size of the impermeable surface (soil sealing: in the range of less than $10 \%$ to $80 \%$ and more), the height of buildings and the presence of vegetation - grass and tree. The area was surveyed using 24 classes (land cover/land use), 18 of which characterize the urban landscape (Szatmári et al., 2018). The minimum area of the identified built-up area is 0.25 ha. These areas can be named as pedo-urban complexes (PUC) with dominant influ- ence of human activities including all anthropogenic impermeable surfaces together with their adjacent permeable areas and vegetation (PUC).

Areas of pedo-urban complexes with a certain proportion of impermeable coverage, were delimited on the basis of the latest ortho-photomaps. At the third and fourth hierarchical level is class 1.1 Urban fabric, which is classified in more detail according to the share of impermeable covered soils (in the range $>80 \%, 50-80 \%, 30-50 \%, 10-30 \%$ and $<10 \%$ ). Classes 2 to 5 , were recognized as agricultural and semi-natural areas, forests, have a minimum area of the identified area of 1 ha and were classified by MKSP (2014) system (Societas pedologica slovaca, 2014) and correlated to the World Reference Base for Soil Resources (IUSS Working Group WRB, 2015).

For the new version of the Slovak anthropogenic soils classification system there were introduced the key features recognizing Anthrozems and Technozems as soil types of technogenic soil group. These key characteristics are 1) human-transported and altered material (HTAM), and 2) artefact content. Technogenic soil group in the Morphogenetic Soil Classification System of Slovakia (Societas pedologica slovaca, 2014) considers Anthrozems and Technozems like soils developed from HTAM and/or having artefacts (vol.). HTAM is human-transported and altered material what has been moved from outside source area 
by human activity (aid of machinery or hand tools), and can be served like parent material for soils. This definition does not include events of erosion, flooding, eolic, colluvial or alluvial activities or natural catastrophe. However, bomb spillage causing soil removing - yes. Three varieties of HTAM layers were distinguished:

- $\quad$ HTAM of natural origin - with share of $<10 \%$ artefacts

- HTAM of natural-technogenic origin with share of $10-40 \%$ artefacts

- $\quad$ HTAM of technogenic origin with share $>40 \%$ artefacts.

Soil types Anthrozem and Technozem (in Slovak connotation) are characterized as ex-situ located material, largely affected by physical-mechanical excavation, transportation and spreading, as well as mixing and can contain some artefacts. Field survey has to involve into description features of anthropedoturbation and pedovariability on which a "new" pedogenesis can take place. Topsoil horizon can be developed as a result of initial pedogenetic processes or as a result of recultivation measures. Also gleyic or stagnogleyic processes are taken into consideration. The cumulative horizons of HTAM for these soil types classification is in thickness $>60 \mathrm{~cm}$. As sub-ordered forms can be named: reductic (contains a high amount of active reductive gas from the anaerobic decomposition of organic matter), ekranic (soil sealing covering more than $80 \%$ area), spoil bank (landfill material containing industrial or mining waste), spolic (landfill material containing garbage with metagenesis), urbic (landfill material containing construction artefacts). These criteria were submitted to the analyses and correlation to the WRB 2015 (IUSS Working Group WRB, 2015).

\section{Results}

Soil map of Bratislava city was created using above mentioned procedure including pedo-urban complexes mapping. The area was vectorised on the background of land cover/land use (LC/LU) sites categorized according to Extended Nomenclature Urban Atlas 2012 (Szatmári et al., 2018). Example of the PUC delineation is illustrated on the Fig. 2. Land cover/land use map showed Fig. 3.

Schema of classification and nomenclature of land cover/ land use was submitted by detailed recognition and compared to the results of urban soil survey from the former investigation (Sobocká, 2007). To delineate PUCs in urban areas there were a need to use satellite images and GIS tools. Urban soil unit's delimitation and digitalization were made in the scale 1:5,000 and digitalized in ArcMap 10.4.1 (C) 2015 Esri). Areas of the PUCs were identified and completed by soil type, or soil associations, of course HTAM and artifacts presence and risky elements (Toxic qualifier). Also percentage of soil sealing was added (mapped as Ekranic qualifier). Cartographic boundaries between PUCs and natural soils copies boundaries of land cover/land use.

As outputs of the soil survey and mapping could be provided Soil map of Bratislava city (Fig. 4 and Fig. 5). This map allowed to provide basic characterization of urban soils in the city. Soil map of Bratislava city consists of 1,478 areas with soil units classify according to MKSP (2014) and IUSS Working Group WRB (2015).

The most common soil unit classified according to IUSS Working Group WRB (2015) within the city (Table 1) is Ekranic Technosol (Relocatic), which practically indicate all sealed areas within the city. These soils are covered by technic hard material, mainly by concrete and asphalt and being in situ remodelled by human activity mainly for reason of building underground infrastructure for city like pipelines, water ducts, power lines etc. Simplified we can say, that these soils were created by sealing and mixing. This soil unit occur in almost every category of artificial surfaces. The unsealed soil units within the city is mainly representing by Urbic Technosol and Regosol (Transportic). Urbic Technosols having $\geq 20 \%$ artefacts in the upper $100 \mathrm{~cm}$ and many of them are also relocate, but in case of Urbic Technosols is supplementary qualifier Relocatic redundant, precisely because of its very frequent occurrence of soil in situ remodelling by human activity. Urbic Technosols are typically for older built urban fabric and formed by long-term deposition, while for newer urban zones are most typical Regosols (Transportic). These soils are created by human transported and deposited soil material moved from a source area, during the post construction works. They usually not having $\geq 20 \%$ artefacts, therefore we cannot classify them as Technosols, although these are soils with strong human influence. In this case, we encounter a lack of IUSS Working Group WRB (2015) in classification of urban soils, when it pays on its strictly non genetic base. It is very modern in post construction works use artificial materials like crusts, sawdust, sand, stones etc. and soil profile is totally created by human activity. In this case we can consider whole soil profile like one artefact and we can classify these soils as Regosol (Technic). Typical soil unit for allotment gardens is Hortic Anthrosol. Allotment gardens mainly occur within discontinues very low, low and medium density urban fabric. We realize, that not all private garden soils having hortic horizon $\geq 50 \mathrm{~cm}$ thick or not all reach the criteria for hortic horizon, but these soils has common feature in their very intensive (mainly positive) agricultural using and they are cultivated by human activity. We consider that this agricultural using is more intensive in general that soils on arable land in open countryside. That is why soils of private gardens we consider as soils with strong human activity - anthropogenic soils, while soils of arable land we consider just as semi-natural soils with Aric as supplementary qualifier. Among semi-natural soils we include also soils of vineyards, which in case of Bratislava city occur on terraces on Little Carpathians slopes and we can classify them Cambisols (Escalic). Very special and important soil unit within the city is Spolic Technosol. This soil unit form only small areas, but they are usually toxic and in many cases they are signed like environmental burden. Linic Technosol is typical soil unit for all roads and railways and associated land. These soils having a continuous impermeable constructed technic hard material on soil surface. They are associated with soils, which were created by transported material during the post construction works. They are very often contaminated by traffic emissions and we can classify them as Regosols (Immissic, Transportic). Green urban areas are mostly represented by $R e$ gosols (Transportic). Special position among green urban areas 


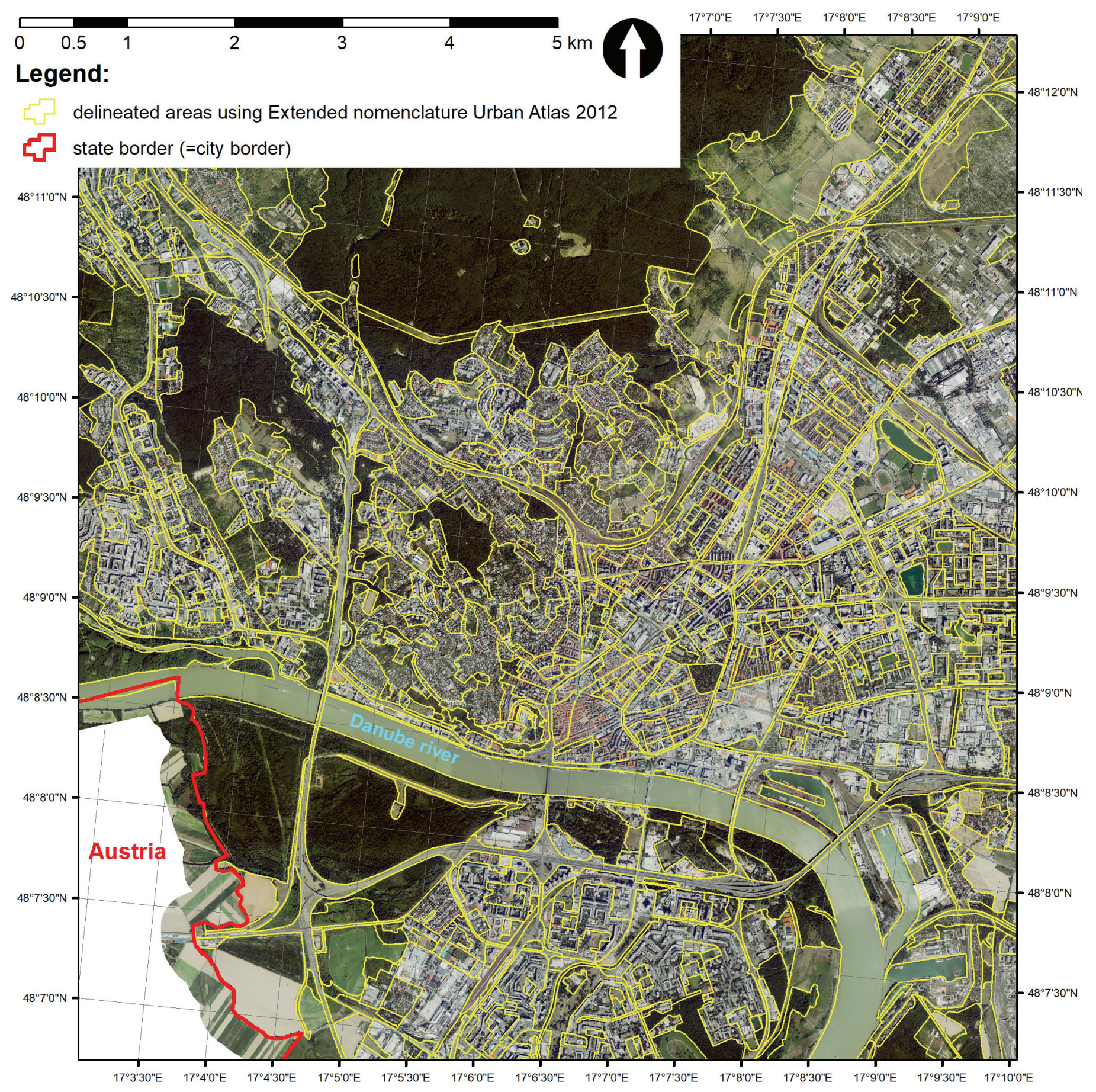

Fig. 2. Delineation of areas using Extended nomenclature Urban Atlas 2012 


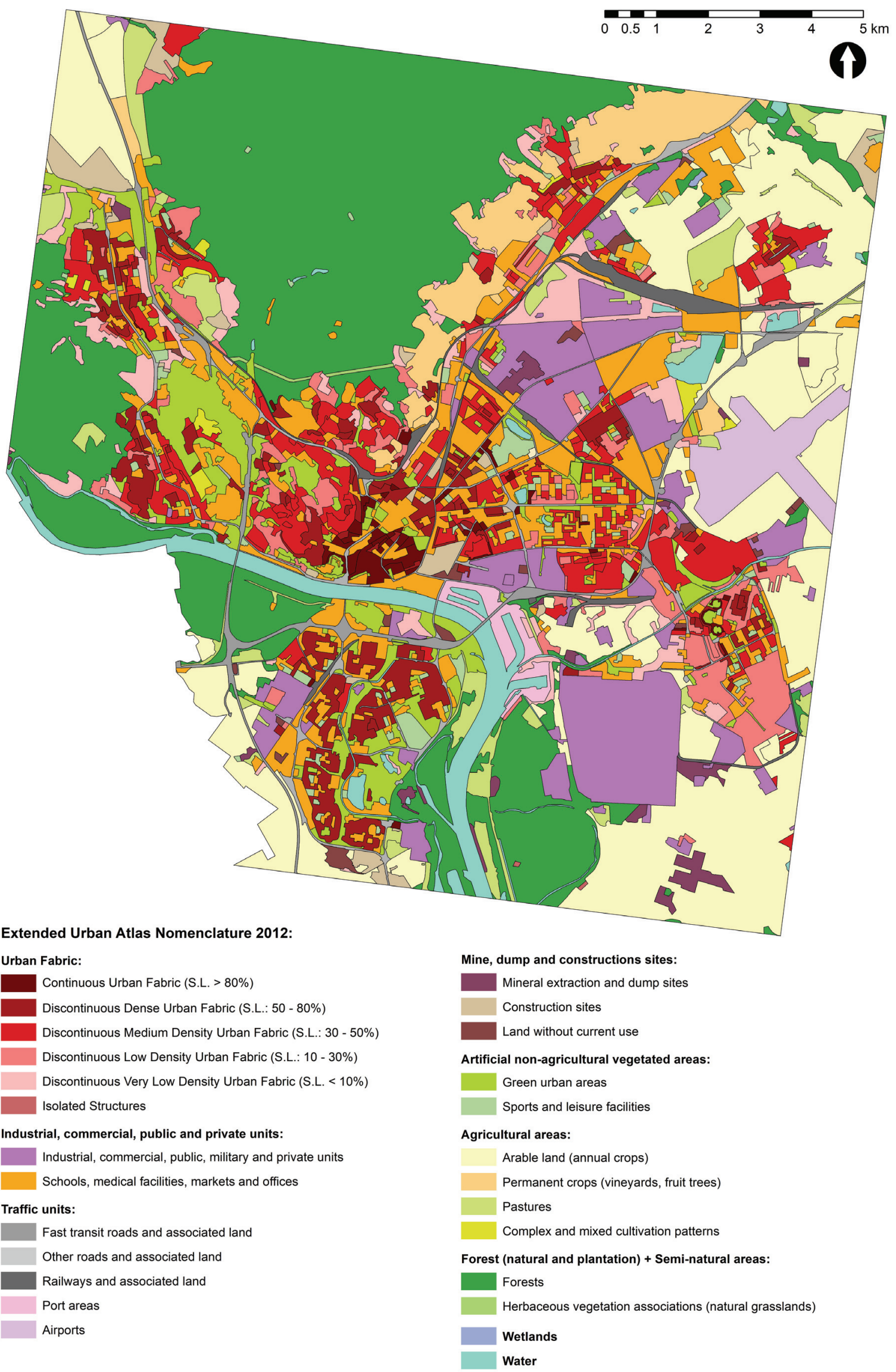

Fig. 3. Land cover/Land use map of Bratislava City 


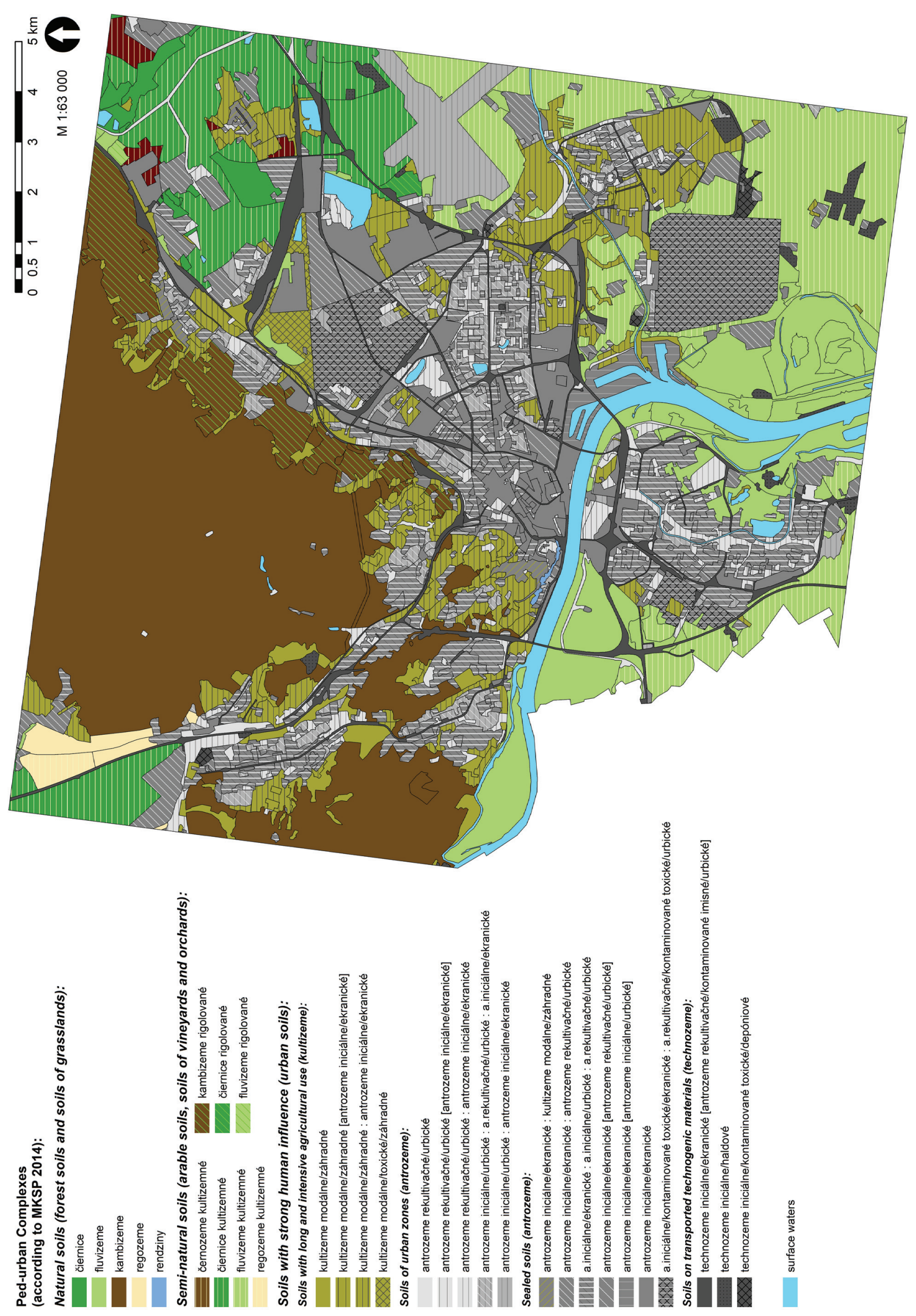




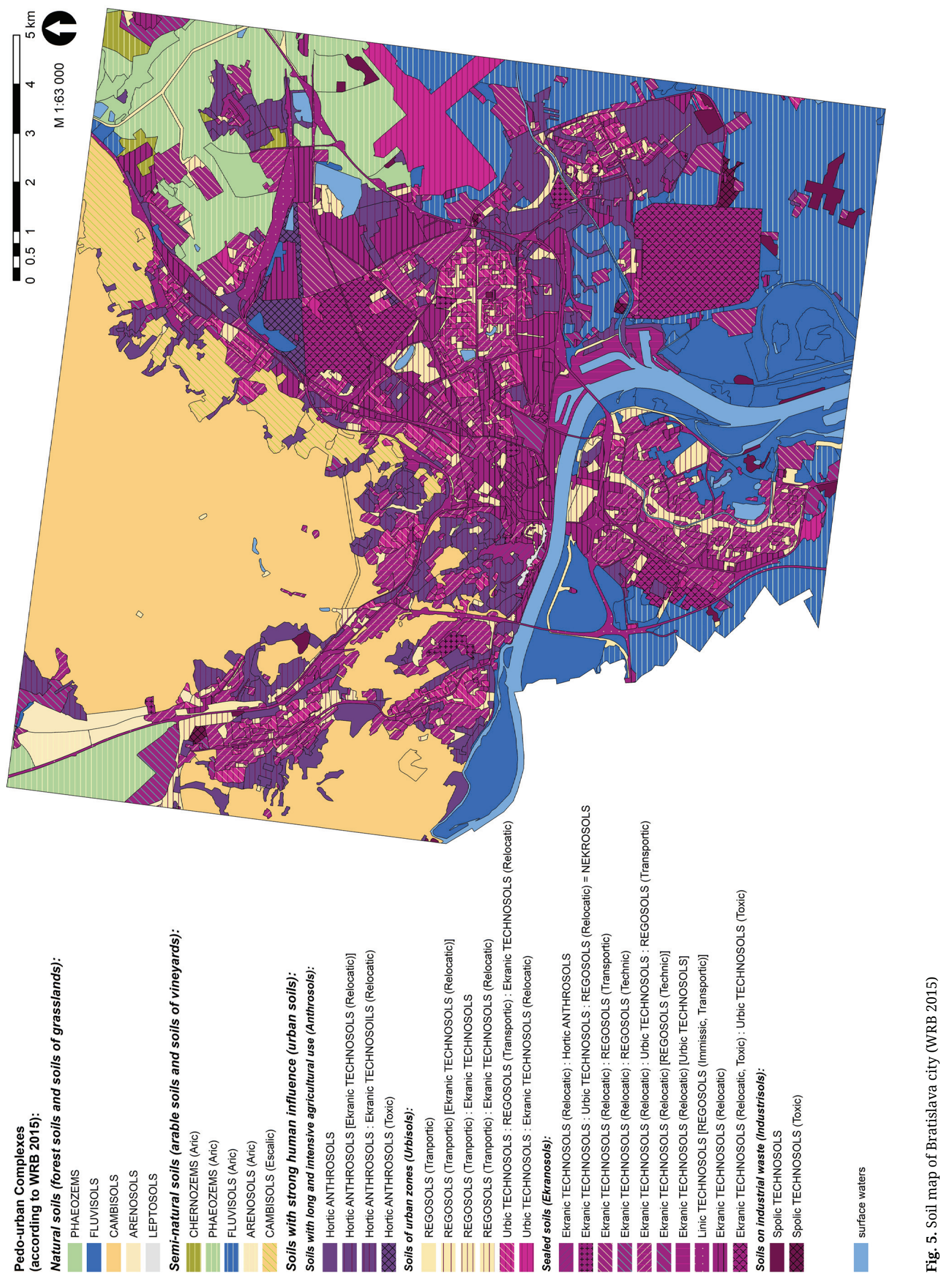




\section{Table 1}

Typical soil units within pedo-urban complexes

\section{Extended nomenclature \\ Urban Atlas 2002: \\ Continuous urban fabric \\ (S.L. > 80\%) \\ Discontinuous dense urban fabric \\ (S.L. 50-80\%) \\ Discontinuous medium density urban fabric (S.L. 50-80\%) \\ Discontinuous low density urban fabric (S.L. 10-30\%) \\ Discontinuous very low density urban fabric (S.L. 10-30\%) = mainly allotment gardens}

Isolated structures

Schools, medical facilities, markets and offices

Production and storage areas

Fast transit roads and associated land

Other roads and associated land

Railways and associated land

Port areas

Airports

Mineral extraction and dump sites

Construction sites (New zones)

Land without current land use

Green urban areas

- Cemeteries:

Sport and leisure facilities

Arable land - annual crops

Permanent crops - vineyards

Pastures

Complex and mixed cultivation patterns

Orchards

Forests

Herbaceous vegetation association

Wetlands

Water
Typical soil units

within pedo-urban complexes:

Ekranic TECHNOSOLS (Relocatic) [Urbic TECHNOSOLS]

Ekranic TECHNOSOLS (Relocatic) : Urbic TECHNOSOLS : REGOSOLS (Transportic)

Ekranic TECHNOSOLS (Relocatic) : REGOSOLS (Transportic) : Urbic TECHNOSOLS

Hortic ANTHROSOLS : Ekranic TECHNOSOLS (Relocatic)

Hortic ANTHROSOLS [Ekranic TECHNOSOLS (Relocatic)]

Hortic ANTHROSOLS or Ekranic TECHNOSOLS (Relocatic)

Ekranic TECHNOSOLS (Relocatic) : Urbic TECHNOSOLS : REGOSOLS (Transportic)

Ekranic TECHNOSOLS (Relocatic) : REGOSOLS (Transportic)

Linic TECHNOSOLS [REGOSOLS (Immissis, Tranportic)]

Linic TECHNOSOLS [REGOSOLS (Immissis, Tranportic)]

Linic TECHNOSOLS [REGOSOLS (Immissis, Tranportic)]

Ekranic TECHNOSOLS (Relocatic) [Urbic TECHNOSOLS]

Urbic TECHNOSOLS : Ekranic TECHNOSOLS (Relocatic)

Spolic TECHNOSOLS - (Toxic)

Garbic TECHNOSOLS - (Toxic)

Ekranic TECHNOSOLS (Relocatic) [REGOSOLS (Technic)]

Urbic TECHNOSOLS : Ekranic TECHNOSOLS (Relocatic)

REGOSOLS (Transportic) [Ekranic TECHNOSOLS]

Ekranic TECHNOSOLS : Urbic TECHNOSOLS : Relocatic REGOSOLS

REGOSOLS (Transportic) : Ekranic TECHNOSOLS (Relocatic)

Semi-natural soils with supplementary qualifier Aric

Semi-natural soils - Eutric CAMBISOLS (Escalic)

Natural soils

Hortic ANTHROSOLS [Ekranic TECHNOSOLS (Relocatic)]

Natural soils

Natural soils

Natural soils

Natural soils

Water

Explanatory notes: First listed soil unit is dominant, “:” mean subdominant (associated) units and "[l” mean local, sporadic soil units. S.L. = Sealed Land 
has cemeteries. There are 18 contemporary cemeteries in Bratislava. Their soils, in general called as Necrosols is representing by mosaic of soils units: Ekranic Technosols, Urbic Technosols and Relocatic Regosols (Charzyński et al., 2011).

\section{Discussion}

Presented technique of urban soil mapping is one of the other contributions to solve the complicated situation of soil mapping in cities. Some items of urban soil mapping are identical to the systems presented with mapping techniques of Moscow (Prokofyeva and Martynenko, 2017), New York (Shaw and Isleib, 2017), German cities (Holland et al., 1997; Schleuss et al., 1998) or Polish cities like Toruń or Zielona Góra (Charzyński et al., 2013; Charzyński and Hulisz, 2017; Greinert, 2015; Hulisz et al., 2018). In the work of Pindral et al. (2020) land use is accepted for the urban soil complex in what soil transformation classes are recognized. They work with the concept that the urban complex includes all the land within the city limits.

Common features involved into the urban soil mapping can be follows: i) geomorphology (physiographic units), ii) historical documentation, iii) land use solving. Very ingenious is the German guideline for soil description (Arbeitskreis Stadtboeden der Deutschen Bodenkundlichen Gesellschaft, 1997; Ad-hoc-AG-Boden, 2005), due to urban soil surveying anthropogenic landforms, surface sealing and technogenic substrates were completed.

Pedo-urban complex can be roughly compared to the soil urban complex in work of (Hulisz et al., 2018; Pindral et al., 2020) or "functional zones" of the work Prokofyeva and Martynenko (2017). However, their definition or spatial delineation is not very clearly defined. The big problem lies in the mapping of soil sealing mainly in smaller scale. E.g. in Osnabruck sealed surfaces defined on the map are only partially sealed, i.e. not precise data (Fachhochschule Osnabrück, 2009). One of the significant feature of urban soil survey is human-transported and altered material which are accepted in works of Shaw and Isleib (2017) or Sobocká (2011). The large areas of HTAM were later enriched in artefacts or other waste materials.

It is necessary to use satellite images or NDVI or infra-red satellite records to process the mapping results. The background need to be more recent, as it captures the current dynamics and transformation of the urban land cover. The means for processing can be used GIS tools or spatial modelling.

Classification of urban soils is a problem in itself. Different approaches to classification systems can be found in the works: Blaize (1998), Stroganova et al. (1998), Lehmann and Stahr (2007), Puskás and Farsang (2009), Prokofyeva et al. (2011), Sobocká (2011), Charzyński et al. (2013), Prokofyeva et al. (2014), Soil Survey Staff (2014), Kabała et al. (2019).

The unifying medium of the mutual consensus of the classification is WRB 2015. Therefore, an important task for the future is to continue to work at this international level on improving the system of mapping urban soils. The mapping of urban soils itself should be the starting point for applied and interpreted maps for the evaluation of soil functions, ecosystem services in urban spatial planning (Séré et al., 2008).

\section{Conclusions}

We consider that the methodology of urban soil research and mapping needs to be better clarified and further develop. What are main obstacles in urban soil survey and mapping? There are several issues:

- $\quad$ to identify and classify soil unit with anthropic features within the city,

- $\quad$ to identify spatial distribution and pedodiversity in the urban land,

- $\quad$ to identify and classify variability of human-transported and altered material,

- $\quad$ to measure inevitable special analytical data of noxious compounds,

- $\quad$ to measure soil sealing with appropriate methods,

- to identify auxiliary data incl. urban site history knowledge,

- $\quad$ to use strong digging technology in urban soil pits and respect tubes, cables and other subsurface elements,

- $\quad$ to respect private owners in cities at digging soil pits.

There is no internationally accepted guidelines for urban soil and urban land mapping. Some problems can rise to deal with definitions of urban soil and anthropogenic soils. Each contribution to this topic is very valuable and could be carefully recognized.

It is necessary for the further development of this pedological discipline in more detailed level. A general lack of experience with urban soils mapping, evaluation and correlation with other classification systems is also insufficient. For the urban landscape planners and designers there is an urgent challenge to include urban soil description, classification and mapping as a helpful tool for their urban planning processes. Also urban survey can identify new important soil types, which can be used to improve current international and national soil classification systems.

\section{Acknowledgments}

This work was supported by the Slovak Research and Development Agency under the contract no. APVV-15-0136.

\section{References}

Ad-hoc-AG-Boden, 2005. Bodenkundliche Kartieranleitung - 5. Auflage, Hannover, 438 pp. (in German)

Arbeitskreis Stadtboeden der Deutschen Bodenkundlichen Gesellschaft, 1997. Empfehlungen des Arbeitskreises Stadtboeden der Deutschen Bodenkundlichen Gesellschaft für die bodenkundliche Kartierung urban, gewerblich, industriell und montan überformter Flächen (Stadtboeden) (Recommendation of the WG Urban Soils of the German Soil Science Society for soil survey of urban, commercial and industrial areas). 2nd edition, part 1: field guide. Sekretariat buero fuer bodenbewertung, Rehsenweg 75, 24148 Kiel. (in German)

Blaize, D., 1998. A Sound Reference Base for Soil, the "referential pedologique”. INRA, Paris, 322 pp. (in English)

Bockheim, J.G., 1974. Nature and Properties of Highly Disturbed Urban Soils. Philadelphia, Pennsylvania. Paper presented before Div. S-5, Soil Science Society of America, Chicago, Illinois. 
Bragina, P., Gerasimova, M., 2017. Why parent materials should be introduced into Technosol systematic? Abstract Book SUITMA 9, Moscow, 16-18.

Bullock, P., Gregory, P.J. (Eds.), 1991. Soils in the Urban Environment. Blackwell Scientific Publications.

Burghardt, W., 1994. Soils in urban and industrial environments. Zeitschrift für Pflanzenernährung und Bodenkunde 157(3), 205-214. https://doi.org/10.1002/jpln.19941570308

Burghardt, W., 2001. Soil of Low Age as Specific Features of Urban Ecosystem. Soil Anthropization VI., Proceedings of the International Workshop, Bratislava (20-22 June 2001), 11-17.

Burghardt, W., Morel, J.L., Zhang, G.L., 2015. Development of the soil research about urban, industrial, traffic, mining and military areas (SUITMA). Soil Science and Plant Nutrition 61(sup1), 3-21. https://doi. org/10.1080/00380768.2015.1046136

Certini, G., Scalenghe, R., 2011. Anthropogenic soils are the golden spikes for the Anthropocene. The Holocene 21(8), 1269-1274. https://doi. org/10.1177/0959683611408454

Craul, P.J., 1992. Urban Soil in Landscape Design. Wiley, 146 pp.

Craul, P.J., 1999. Urban Soils: Applications and Practices. Wiley, 384 pp.

Charzyński, P., Bednarek, R., Chmurzyński, M., 2011. Właściwości gleb tworzących się na budowlach miasta Torunia. [In:] Jankowski, M. (Eds.), Wybrane problemy genezy, systematyki, uźytkowania i ochrony gleb region kujawsko-pomorskiego. PTSH Wrocław, PTG Warszawa, 97-116. (in Polish)

Charzyński, P., Bednarek, R., Greinert, A., Hulisz, P., Uzarowicz, L., 2013. Classification of technogenic soils according to WRB system in the light of Polish experiences. Soil Science Annual 64(4), 145-150. http://dx.doi.org/10.2478/ssa-2013-0023

Charzyński, P., Hulisz, P., 2017. The case of Toruń, Poland. [In:] Levin, M.J. (Eds.), Soils within Cities. Schweizerbart Science Publisher.

Charzyński, P., Plak, A., Hanaka, A., 2017. Influence of the soil sealing on the geoaccumulation index of heavy metals and various pollution factors. Environmental Science and Pollution Research 24, 4801-4811. https://doi.org/10.1007/s11356-016-8209-5

De Kimpe C.R., Morel, J.-L., 2000. Urban Soil Management: A Growing Concern. Soil Science 165(1). 31-40. DOI: 10.1097/00010694200001000-00005

Deutschen Bodekundlichen Geselschaft, 1998. Systematik der Boden und der bodenbildenden Substrate Deutschlands. Band 86.

Fachhochschule Osnabrück, 2009. Funktionsbewertung urbaner Böden und planerische Umsetzung im Rahmen kommunaler Flächenschutzkonzeptionen - Stadtboden: Endbericht; REFINA Forschungsvorhaben. Technische Informationbibliothek u. Universitätsbibliothek, 249 pp. https://doi.org/10.2314/GBV:613150287

Feranec, J., Holec, J., Št́astný, P., Szatmári, D., Kopecká, M., 2019a. Visualising a comparison of simulated urban heat islands: a case study of two Slovakian cities. Advances in Cartography and GIScience of the International Cartographic Association, 29th International Cartographic Conference (ICC), Tokyo (15-20 July 2019).

Feranec, J., Kopecká, M., Szatmári, D., Holec, J., Štastný, P., Pazúr, R., Bobálová, H., 2019b. A review of studies involving the effect of land cover and land use on urban heat island phenomenon, assessed by means of the MUKLIMO model. Geografie 124(1), 383-101.

Geological map of Slovakia M 1:50,000 [online]. Bratislava: Štátny geologický ústav Dionýza Štúra, 2013. Available on internet: http://apl. geology.sk/gm50js (in Slovak).

Greinert, A., 2015. The heterogeneity of urban soils in the light of their properties. Journal of Soils and Sediments 15, 1725-1737. https://doi. org/10.1007/s11368-014-1054-6

Hernandez, L.A., Galbraith, J.M., 1997. USDA-NRCS. Soil Survey of LaTourette Park, Staten Island. USDA-Natural Resources Conservation Service, Lincoln, Nebraska and Cornell University.

Holland, K., Lehmann, A. \& Stahr, K., 1997. Bodeninventur in Stuttgart. [In:] Blume, H.P., Schleuss, U., (Eds.), Bewertung anthropogener Stadt- böden. Abschlussbericht des BMBF-Verbundvorhabens der Universitäten Berlin (TU), Halle-Wittenberg, Hohenheim, Kiel und Rostock sowie des „Büro für Bodenbewertung“, Kiel. Schriftenreihe Institut für Pflanzenernährung und Bodenkunde \& Ökologie Zentrum, Universität Kiel 38, 281-307. (in German)

Hraško, J., Linkeš, V., Šály, R., Šurina, B., 1993. Soil Map of Slovakia 1:400 000. Soil Fertility Research Institute, Bratislava. (in Slovak)

Hulisz, P., Charzyński, P., Greinert, A., 2018. Urban soil resources of medium-sized cities in Poland: a comparative case study of Torun and Zielona Góra. Journal of Soils and Sediments 18, 358-372. https://doi. org/10.1007/s11368-016-1596-X

Huot, H., Joyner, J., Córdoba, A., Shaw, R.K., Wilson, M.A., Walker, R., Muth, T.R. \& Cheng, Z., 2017. Characterizing urban soils in New York City: profile properties and bacterial communities. Journal of Soils and Sediments 17, 393-407. https://doi.org/10.1007/s11368-016-1552-9

IUSS Working Group WRB, 2006. World Reference Base for Soil Resources 2006. World Soil Resources Reports No. 103, FAO, Rome.

IUSS Working Group WRB, 2015. World Reference Base for Soil Resources 2014. Update 2015. International soil classification system for naming soils and creating legends for soil maps. World Soil Resources Report No. 106, FAO, Rome.

Kabała, C. et al., 2019. Polish Soil Classification, $6^{\text {th }}$ edition - principles, classification scheme and correlations. Soil Science Annual 70(2), 71-97. https://doi.org/10.2478/ssa-2019-0009

Kottek, M., Grieser, J., Beck, C., Rudolf, B., Rubel, F., 2006. World Map of the Koppen-Geiger climate classification updated. Meteorologische Zeitschrift 15, 259-263. DOI: 10.1127/0941-2948/2006/0130

Lehmann, A., Stahr, K., 2007. Nature and significance of anthropogenic urban soils. Journal of Soils and Sediments 7, 247-260. https://doi. org/10.1065/jss2007.06.235

Lehmann, A., 2009. Andears Lehmann, Susanne David, Karl Stahr: TUSEC - technique for soil evaluation and categorization for natural and anthropogenic soils. Volume 85, 'Hohenheimer Bodenkundliche Hefte'. Journal of Soils and Sediments 9, 111. https://doi.org/10.1007/ s11368-009-0071-3

Levin, M.J. et al., 2017. Soil within Cities (Global approaches to their sustainable management - composition, properties, and functions of soil of the urban environment). Schweizerbart Science Publishers.

Makowsky, L., 2009. Bewertung der Schwermetall-Mobilität von Stadtböden aus technogenen Substraten bei Elution von Bodensäulen im Dynamischen Batchtest. Shaker Verlag, Aachen. (in German)

Makowsky, L., Schneider, J., 2017. The case of Germany. [In:] Levin, M.J. et al. (Eds.), Soils within Cities. Schweizerbart Science Publishers.

Mazúr, E., Lukniš, M., 1980. Regional geomorphological delimitation 1:500 000. The Geographical Institute of the Slovak Academic of Sciences, Bratislava. (in Slovak)

Morel, J.L., Heinrich, A.B., 2008. SUITMA - soils in urban, industrial, traffic, mining and military areas. Journal of Soils and Sediments 8, 206-207. https://doi.org/10.1007/s11368-008-0023-3

Montanarella, L. et al., 2016. World's soils are under threat. Soil, 2, 79-82. https://doi.org/10.5194/soil-2-79-2016

Pindral, S., Kot, R., Hulisz, P., Charzyński, P., 2020. Landscape metrics as a tool for analysis of urban pedodiversity. Land Degradation \& Development. https://doi.org/10.1002/ldr.3601

Prokofyeva, T.V., Martynenko, I.A., Ivannikov, F.A., 2011. Classification of Moscow soils and parent materials and its possible inclusion in the classification system of Russian soils. Eurasian Soil Science 44, 561. https://doi.org/10.1134/S1064229311050127

Prokofyeva, T.V., Gerasimova, M.I., Bezuglova, O.S., Bakhmatova, K.A., Goleva, A.A., Gorbov, S.N., Zharikova, E.A., Matinyan, N.N., Nakvasina, E.N. and Sivtseva , N.E., 2014. Inclusion of soils and Soil-like bodies of urban territories into the Russian soil classification system. Eurasian Soil Science 47, 959-967. https://doi.org/10.1134/S1064229314100093

Prokofyeva, T.V., Martynenko, I.A., 2017. The case of Moscow, Russia. [In:] Levin, M.J., (Eds.), Soils within Cities. Schweizerbart Science Publisher. 
Puskás, I., Farsang, A., 2009. Diagnostic indicators for characterizing urban soils of Szeged, Hungary. Geoderma 148(3-4), 267-281. https:// doi.org/10.1016/j.geoderma.2008.10.014

Rossiter, D.G., 2007. Classification of urban and industrial soils in the World Reference Base for Soil Resources. Journal of Soils and Sediments 7, 96-100. https://doi.org/10.1065/jss2007.02.208

Schleuss, U., Wu, Q., Blume, H.-P., 1998. Variability of soils in urban and periurban areas in Northern Germany. Catena 33(3-4), 255-270. https://doi.org/10.1016/S0341-8162(98)00070-8

Shaw R.K., Isleib J.T., 2017. The case of the New York City Soil Survey Program, United States. [In:] Levin, M.J. et al. (Eds.), Soils within Cities. Schweizerbart Science Publisher.

Shaw, R.K., Hernandez, L.A., Levin, M.J., Muńiz, E., 2018. Promoting soil science in the urban environment - partnerships in New York City, NY, USA. Journal of Soils and Sediments 18, 352-357. https://doi. org/10.1007/s11368-016-1456-8

Séré, G., Schwartz, C., Ouvrard, S., Sauvage, C., Renat, J.C., Morel, J.L., 2008. Soil construction: a step for ecological reclamation of derelict lands. Journal of Soils and Sediments 8, 130-136. https://doi.org/10.1065/ jss2008.03.277

Sobocká, J., 2003. Urban Soils vs. Anthropogenic Soils, their Differentiation and Classification. Final Program and Abstracts Book, SUITMA International Conference (9-11 July, 2003), Nancy, France, 41-42.

Sobocká, J., 2007. Urbánne pôdy - príklad Bratislavy. (Urban soils - A Case Study of Bratislava). Soil Science and Conservation Research Institute, Bratislava, 2007, 174 pp. (in Slovak)

Sobocká, J., 2011. Návrh inovácie skupiny antropogennych pod v MKSP 2000 (definícia, diagnostika, klasifikácia) (A proposal of innovation of anthropogenic group in MKSP 2000 (definition, diagnostics, classification)). [In:] Sobocká, J., (Eds.), Diagnostika, klasifikácia a mapo- vanie pôd. Soil Science and Conservation Research Institute, Bratislava, 2011, 118-125. (in Slovak)

Societas pedologica slovaca, 2014. Morfogenetický klasifikačný system pôd Slovenska. Bazálna referenčná taxonómia (Morphogenetic Soil Classification System of Slovakia. Bazal Reference Taxonomy). The second revised edition. NPPC-VÚPOP, Bratislava, 96 pp. (in Slovak)

Soil Survey Staff, 2014. Keys to Soil Taxonomy. United States Department of Agriculture, Natural Resources Conservation Service, Twelfth Edition, $372 \mathrm{pp}$.

Stadt Stuttgart, 2016. Der Stuttgarter Bodenatlas (Soil Atlas of Stuttgart, 1:20 000). Stadt Stuttgart. Amt für Umweltschutz.

Stroganova, M.N., Miagkova, A.D., Prokofyeva, T.V., 1997. The role of soils in urban ecosystems. Eurasian Soil Science 30(1), 82-86.

Stroganova, M.N., Miagkova, A.D., Prokofyeva, T.V. and Skvortsova, I.N. 1998. Soils of Moscow and Urban Environment. PAIMS, Moscow, $178 \mathrm{pp}$.

Szatmári, D., Kopecká, M., Feranec, J., Sviček, M., 2018. Rozšírená legenda Urban Atlas 2012 (Extended nomenclature Urban Atlas 2012). Institute of Geography, Slovak Academy of Sciences, Bratislava. (in Slovak)

Tonkonogov, V.D., Lebedeva, I.I., 1999. A System for Categorizing Technogenic Surface Formations (Humanly Modified Soils). [In:] Kimble, J.M., Ahrens, R.J. and Bryant, R.B. (Eds.), Classification, Correlation and Management of Anthropogenic Soils. Proceedings Nevada and California Workshop. USDA-NRSC, National Soils Survey Centre, Lincoln, Nebraska, U.S., 186-189.

Vrščaj B., Poggio L., Ajmone Marsan F., 2008. A method for soil environmental quality evaluation for management and planning in urban areas. Landscape and Urban Planning 88(2-4), 81-94. https://doi. org/10.1016/j.landurbplan.2008.08.005 